\title{
The Complexity of Substantive Reform: A Call for Interdependence Among Key Stakeholders
}

Michelle D. Young, Ph.D.

George J. Petersen, Ph. D.

Paula M. Short, Ph.D.

Paper Commissioned for the first meeting of the

National Commission for the Advancement of Educational Leadership Preparation

“Ensuring Universities' Capacity to Prepare Learning Focused Leadership"

Wingspread Conference Center, Racine, Wisconsin

September 19.21, 2001

Sponsored by

University Council for Educational Administration National Policy Board for Educational Administration and

The Johnson Foundation 


\section{The Complexity of Substantive Reform: A Call for Interdependence Among Key Stakeholders}

The field of educational leadership faces serious challenges in the $21^{\text {sl }}$ century. To name but a few, these challenges include the shortage of principals and superintendents, the growing demands of leadership positions, the struggle for adequate resources, the increasing trend to seek leaders from outside of education, and the content and effectiveness of school leadership preparation and professional development. Although each of these challenges could be viewed as separate issues that warrant sustained and serious attention, it is also important to point out their interdependencies. Like many issues confronting our nation today, the challenges facing educational leadership are complex and interconnected.

This paper explores the challenges facing educational leadership from the position of university educational leadership' preparation. The approach we take looks inward and outward, seeking to understand the complex factors and interconnections that support and detract from quality leadership preparation. In this manuscript, we approach the terrain of educational leadership as geographers might approach a valley. We explore contexts in terms of the factors that produce them and interdependencies with other issues and contexts.

\section{A National Focus on Leadership}

Over the past two years, mounting national attention has focused on educational leadership. The Department of Education, the Annenberg Foundation, the Broad Foundation, the Ford Foundation, the Carnegie Corporation of New York, Wallace Funds, state governors and educational officials, and the leaders of several national corporations have all expressed interest in the training and preparation of school leaders. Their focus on this issue has brought with it millions of dollars in research and program funding. For example, before he left office, President Clinton asked Congress to set aside $\$ 40$ million in the FY 2001 budget for the professional development of current and prospective school leaders in what was called the School Leadership Initiative. Similarly, the Annenberg Foundation alone has spent over $\$ 50$ million on educational leadership issues. At the end of 2001 , a figure close to $\$ 100,000,000$ will have been invested in school leadership.

Additionally, educational newspapers, like Education Week, and more widely read newspapers like the New York Times and USA Today, have not only covered stories on broad leadership issues but they too have focused on leadership preparation and professional development. These articles have been, for the most part, critical of traditional university preparation of school and school system leaders and/or hopeful about the possibilities of alternative preparation programs. For example, last fall Education Week ran several articles focused on alternative preparation strategies. One focused on the Army War College. "The US Army War College has been training top military personnel for a century. Does it know something about leadership that educators don't?" (Education Week, November 15, 2000, p. 33). A second focused on newly developed non-profit organization. "New non-profit organization, similar to Teach for America, created to prepare individuals with leadership potential for principalships in urban schools. Believes it can do the job better than universities" (Education Week, September 20, 2000, p. 6). This organization was eventually awarded $\$ 5,000,000$.

In the widely read educational magazine, the Kappan, Haller, Brent, and McNamara (1997), posed the question “Does Graduate Training in Educational Administration Improve America's Schools?" Given the complexity of this issue, their findings were inconclusive. Yet, their comments reached toward negative conclusions. In a later issue of the Kappan, which focused on school leadership, the following statements appeared.

Not only is it difficult to attract qualified candidates, but the training candidates receive from administrator preparation programs is often inadequate, and ongoing professional development is episodic at best. Many university programs are not closely aligned with the instructional and real-world demands principals face. (Phi Delta Kappan, Tirozzi, February 2001, p. 437) 
Our current training system is inadequate, because programs reflect a rearview mirror approach to leadership. Most of the coursework now required for licensure prepares people for the old role-centralized, command-and-control management. It fails to recognize that leadership for the future will be about communication, collaboration and navigating white water (Phi Delta Kappan, Houston, February 2001, p. 432).

The above examples are representative of the current popular opinion of university-based educational leadership preparation (i.e., that it is inadequate). As James Guthrie, the Chairman of Educational Leadership at Vanderbilt, and Ted Sanders, the Chief Executive of the Education Commission of the States, recently wrote:

Over the past quarter century, university preparation of educational administrators has fallen into a downward spiral dominated by low-prestige institutions, diploma mills, outmoded instruction and low expectations. Many of these sub-par training programs have virtually no entrance requirements, save an applicant's ability to pay tuition. The doctor of education (Ed. D.) degrees they confer have lost their salience. In former times big-league education leaders tended to be graduates of institutions like Harvard, Yale, Duke or the University of Chicago. This is no longer true.... Today's conventionally prepared superintendent is more likely to have come from East Appalachia State, San Francisco State or literally hundreds of other public institutions that began as normal schools and politically bootstrapped themselves to graduate degree status. (Guthrie \& Sanders, 2001)

Although many practitioners and professors consider this essentialization of preparation programs an unfair overgeneralization, most agree that there are too many ineffective programs currently operating and have repeatedly called for drastic reform and restructuring of educational leadership preparation (see for example, Achilles, 1990; Bridges, 1992; Capper, 1993; Culbertson \& Hencley, 1962; Lomotey, 1989; McCarthy \& Kuh, 1997; Milstein, 1993; Miklos \& Ratsoy, 1992; Murphy, 1992; Murphy \& Forsyth, 1999; Osterman, 1990; Parker \& Shapiro, 1992; Wendel, 1992). Furthermore, "the desire to improve this profession is widespread" (Murphy \& Forsyth, 1999, p. 263).

The mounting attention, intense criticism, and calls for change are reminiscent of a recent period in the short history of educational leadership. Approximately 16 years ago the public schools' capacity to educate children and the university's ability to prepare school and schoolsystem leaders were severely questioned (Griffiths, Stout, \& Forsyth, 1988). In response, a blueribbon commission was established to study and create a blueprint for change that would revitalize the preparation of educational leaders and take the profession into the next century (Forsyth, 1999). This National Commission on Excellence in Educational Administration (NCEEA) forwarded eight recommendations

calling for the redefinition of educational leadership; the establishment of a national board to shape policy related to school administration; the modeling of administrator preparation programs after other professional schools; a reduction in the number of preparation programs; the increased recruitment, preparation, and placement of ethnic minorities and women; the establishment of partnerships with the public schools in the preparation of school administrators; increased emphasis on professional development or practicing administrators; increased emphasis on professional development for practicing administrators; and reform of licensure and certification. (Forsyth, 1999, p. 75, see also Griffiths, Stout \& Forsyth, 1988)

These recommendations influenced thinking about school leadership and gained widespread endorsement. Indeed, in the years following NCEEA's work, the Danforth Foundation launched a major initiative to support innovate principal preparation programs, the National Policy Board in Educational Administration was created, and across the nation states engaged in efforts to strengthen standards designed to ensure the quality of administrator training. However, as Forsyth pointed out, "few [of the commission's goals] have been unambiguously achieved" (p. 76). There are complex reasons for this, some which we will be discussing below. What is important to point out here, though, is that leaders in the field and the professoriate responded to the need for change in educational leadership preparation and practice proactively. 


\section{Substantive Change Requires Collaboration}

Although the attention educational leadership, in particular university preparation, is receiving is primarily critical in nature, it presents a tremendous opportunity for positive and substantive change. We have before us an opportunity to critically examine and generatively discuss the complex factors and interconnections that support and detract from quality leadership preparation. It is an opportunity to design recommendations for supporting positive substantive change in educational leadership preparation. Moreover, it is an opportunity to which we must commit ourselves.

It is our position that key to the success of any effort to positively and substantively change the preparation of school and school-system leaders is a commitment among key stakeholders to finding common ground and working interdependently toward the realization of mutually agreed upon goals. No single organization, group, or individual can create the kind of changes for leadership preparation that our nation's children need and deserve.

The challenges that face educational leadership preparation are multifaceted and complex. Neither reactionary behavior, such as caustic remarks or finger pointing, nor well-intentioned developments, like alternative certification, will fix educational leadership preparation. There are no simple solutions, no quick fixes. Even national standards cannot, in and of themselves, improve the preparation and professional development of educational leaders. Rather, our approach to supporting positive change must be comprehensive and indicative of the interdependent nature of our work and our actions. Indeed, as a field we must understand that with regard to leadership preparation and practice, we are interdependent. What we do in our work as individuals, groups, and organizations impacts educational leadership preparation and practice. And just as we are all implicated in the current state of leadership preparation, we are collectively responsible for its future.

Criticisms have been made about the selection process of university preparation programs in departments of educational leadership. Some observers believe that this is a significant problem with the quality of candidates and leaders in America's schools. It is essential that we discontinue thinking and operating as independent entities. Our efforts to prepare school leaders are interdependent. One example involves the students who enroll in educational leadership programs (see Griffiths, et.al.1988, p. 290). Research has clearly demonstrated that students enter educational leadership programs for many reasons, and some have no intention of becoming school administrators (McCarthy, 1999). Furthermore, concerns have been raised about the quality of the students entering programs and whether some should ever lead a school. Because it is educational leadership programs that admit individuals to their programs, many critics effortlessly locate issues of student intention, quality, and competence within program standards and screening.

Unfortunately, this issue is not so straightforward. Who applies and is admitted into educational leadership programs is affected by a large number of factors. For example, who applies is generally affected by: individual decisions and goals; encouragement from a mentor or colleague; program location; number of hours required to complete the program; financial cost of completing the program; recommendations from professional associations, colleagues, mentors and family members; graduate school entry standards; program entrance standards; program recruitment strategies; administrative internship requirements; program difficulty; and program quality. Who is admitted may be impacted by who applies as well as graduate school and program entrance standards, the rigor and thoroughness of the program's entry process, the size and quality of the applicant pool, state licensure mandates, and student enrollment numbers.

Although the standards of some educational leadership programs are woefully inadequate and deserve criticism, and while increasing the selectivity of entrance criteria nationwide would go a long way toward addressing the issue of student quality, this solution, alone, is inadequate. Program standards do not (directly) impact any of the following: individual decisions and goals; encouragement received, program location; number of hours required to complete the program; financial costs; recommendations from professional associations, colleagues, mentors and family members; graduate school entry standards; program recruitment strategies; administrative internship requirements; program difficulty; program quality; size and quality of the applicant pool; state licensure mandates; and student enrollment numbers. Comprehensively addressing the issues of 
who applies and is admitted to preparation programs will require collaboration between universities, practitioners, professional organizations, and state licensing agencies, among others.

Collaboration is a necessary ingredient for the improvement of preparation programs. The students who apply and are admitted to preparation programs constitute only one of the interdependent issues impacting school leadership preparation that will require a planned collective response. Others include program content, program development, program delivery, and program resources to name only a few. Various professional organizations, state and federal agencies, university professors, higher education organizations, foundations, and practitioners have expressed commitments to the improvement of leadership preparation. Many have exhibited a long-standing engagement in improvement efforts.

Associations have devoted their energies and funds; state governments, national consoritia, foundations, study panels, and countless groups of professional school faculty and practitioners have thought about the leverage points that might be used to stimulate improvement in preparation; and all of these have mounted reform initiatives. (Murphy \& Forsyth, 1999, p. 263)

Unfortunately, few of these initiatives have been joint endeavors. Again, key to the success of any effort to positively and substantively improve the preparation of educational leaders is a commitment among key stakeholders to collaborate. It is important that we capitalize on the extraordinary level of commitment to improving leadership preparation and practice through a wellplanned collective effort.

We have in our grasp an opportunity to build a future in which leaders are prepared to support the education and success of all children. In order to do this, however, we must focus and use our resources to support program efforts and research that move us in this direction. Efforts such as that proposed through the development of the National Commission for the Advancement of Educational Leadership Preparation (NCAELP) embody this opportunity and have the potential to play an important role in this critical effort.

\section{Current Context Presents Challenge for Leadership Preparation}

Intense criticism has been focused on educational leadership preparation programs for the past few decades, yet little effort or importance has been dedicated to a comprehensive analysis ${ }^{2}$ or discussion of these criticisms and/or their targets. If it is the case, as Guthrie and Sanders (2001) claim, that university preparation is in a downward spiral, it seems that a broad examination would be in order. More importantly, if we are to improve the preparation of educational leaders, then we must also understand why some programs are having a difficult time providing quality preparation experiences.

Although it is often the case that rhetoric outstrips reality in the area of program reform, programs across the nation have engaged in program improvement efforts. Yet, some faculty report that their efforts have, at worst, failed or been thwarted and, at best, received little support or recognition. In the above paragraphs, we have alluded to some of the complex factors impacting educational leadership preparation. These factors also include the following:

- Institutional Support for Educational Leadership Programs

- Faculty Professional Development

- Increased Numbers of Preparation Programs

- Pool of Capable and Diverse Applicants

- Ongoing Program Enhancement

- Program Content and the Work of School Leaders

- Licensure and Accreditation

- Centering Our Profession on Children

These factors, which are discussed below, do not adequately capture all of those impacting university preparation programs. They do, however, draw attention to some of the most exigent concerns.

Institutional Support for Educational Leadership Programs

It is not uncommon for high-ranking university officials to know very little about their 
educational leadership preparation programs. The loose coupling of organizations like universities, particularly the modern research university, makes it difficult for university leaders to be familiar with more than a few of the programs in each of their colleges. This is problematic for a number of reasons, all of which are related to institutional support.

First, when university administrators know little about their educational administration programs, they also may know very little about the resource needs of that program. For example, as educational administration programs seek to build a closer and more substantive relationship between theory, the findings of research, and practice, many are developing closer ties to the field. In their efforts to develop stronger ties, programs are seeking to hire more faculty with administrative experience, to build intensive and longitudinal internship experiences, to provide training in field-based settings, and to conduct applied research (McCarthy, 1999; Murphy, 1999b; Skakeshaft, 1999). Additionally, as programs seek to become more focused on student outcomes, many are dedicating more time to and collaborating with colleagues on devising growth plans for individual students, advising students, monitoring student progress, team-teaching courses, and observing students in their schools (Shakeshaft, 1999).

In order for these changes in program focus and program delivery to be effective, programs will require increased resources and changes in university norms for promotion and tenure. With regard to the latter, the inclusion of more faculty with practical orientations necessitates changes in how entry level salaries and professorial status (i.e., assistant, associate or full professor) are determined. The presence of more faculty with practical expertise and the changes in program orientations toward the field will also require a reconsideration of typical promotion and tenure criteria (e.g., 20\% service, $40 \%$ research, $40 \%$ teaching). Moreover, as program orientations shift toward the field, more faculty time must be dedicated toward field supervision, student advising and monitoring, and faculty planning and coordination among other activities. If these changes are to be made in a meaningful and sustainable way, most programs will require an expansion of the number and type of their faculty and/or modified teaching loads for their faculty.

Unfortunately, while some university leaders appear receptive to the idea of developing new types of partnerships between the academy and schools, few are willing to adjust their reward systems to ensure the development of meaningful relationships or the delivery of substantive services. For example, "there is little evidence that institutions of higher education are embracing an expanded definition of research.... Academe has always valued discovery more than the application of knowledge" (McCarthy, p. 205). Moreover, few universities value team teaching or supervision on field-based internships when calculating faculty load. And instead of increasing faculty lines, many programs are experiencing reductions in faculty lines that are not being offset by new hires. Consequently, these hopeful shifts in preparation programs, may disadvantage faculty in terms of promotion, tenure, and annual reviews (McCarthy, 1999; Murphy \&Forsyth, 1999).

Indeed, if faculty do focus on activities that run counter to institutional norms, they simply will not survive in academe. If this happens, the pendulum might then swing back, with the emphasis on field connections diminishing and units seeking scholars with strong research records in traditionally valued areas. (McCarthy, 1999, p.205)

A related form of institutional support is that of regard. Although not well known to the larger university community, educational administration programs are known of by college of education faculty and administration. Regrettably, over time many educational administration programs have slipped from programs that were held in high regard to programs that are considered notorious for their traditional orientations and resistance to change (Murphy, 1999b). Unfortunately, quality and substandard programs alike are frequently affected by this characterization. Thus, those programs that are increasing their quality and focusing on change and improvement often fail to receive the recognition, commendation, or support that they deserve. This is significant. In the field of educational administration, it is important to have the support and respect of the dean and the larger college community. Support or lack thereof impacts how students (both in the teaching and administrative field) in the college feel about educational leadership in general and how practitioners in the field feel about the quality of the training they can receive at a given university. 


\section{Faculty Professional Development}

As noted above, the lack of visibility of educational administration programs at the university level does not bode well with regard to garnering the resources needed for effective program change and continual development. This is particularly true in those states that have been marked by decreasing state support for higher education. In these states tighter budgets have translated into reduced resources for faculty professional development. Indeed in recent years there has been a constriction in resources allocated to faculty professional development (Murphy, 1999b).

Although there has been an increase in development opportunities for faculty over the past decade, programs and opportunities for faculty professional development are rather scarce. Most faculty receive their professional development either at conferences or by reading on their own. The quality of these opportunities and their relevancy to the changes faculty are making (or need to make) in their programs, however, is unknown. According to Murphy (1999b)

with a few distinct exceptions, nearly all of the professional development opportunities were individualistic in nature.... Very little of it seemed to be organizationally anchored.... [and] with a few clear examples, very few of the professional development experiences were linked to the continuous work of building stronger educational administration programs - the type of improvement work that is at the heart of professional development for school-based educators.

Professional growth opportunities that support program changes like the development of partnerships with schools would be valuable at this juncture. Furthermore opportunities for faculty to share experiences with program changes across universities would go a long way in the planning and implementation of program enhancement efforts.

A promising development in the area of professional development is the growth of professional groups dedicated to teaching in educational administration and program reform. For example, several interest groups have developed over the last year that highlight program content and instructional strategies. These groups include Teaching in Educational Administration, Leaders for Social Justice, a UCEA special interest group on the IESLP project, several UCEA program centers, and an AERA special interest group on problem based learning. Additionally a number of national networks of program reforms have been developed and supported by the Danforth foundation. These developments reflect the renewed commitment to the practical facet of the profession and the strong sense of change valued by many educational administration faculty.

\section{Increased Numbers of Preparation Programs}

The argument that increased competition from private and non-profit alternative certification programs will force university preparation programs to improve, in our current context, is misleading. The idea here is that those seeking licensure in educational leadership, being critical consumers, will choose a program that they believe will best prepare them for school or schoolsystem leadership. As is the case in parental choice of schooling, selection of programs are rarely based upon valid measures of quality.

We would like to begin with an example. Since Hosfstra University began restructuring and improving its program in the late 1980s, it has experienced a decline in enrollments. The increased demands of the Hofstra program and their use of sequenced courses, among other things, resulted in a smaller (though certainly more serious) pool of students interested in their program (Shakeshaft, 1999).

Although the faculty is not unhappy that we have a more serious -if smaller-student body, others within the university are not as enthused as we are with this change. Thus, we have come in for criticism and have lost a tenure-track position from the department. (p. 242) Educational administration programs have historically attracted large numbers of students and generated a large amount of revenue for their universities. However, as programs increase their standards and improve, they often find that their student enrollments decrease. "Balancing market requirements of the university with the educational goals of the faculty is a difficult and potentially dangerous ${ }^{3}$ activity" (p. 242). 
Furthermore, increasing competition in the current context is not causing programs to offer the best there is to offer. In fact, it is currently having the opposite effect on many preparation programs. Students seeking licensure in school administration do not appear "unwilling to devote adequate time and effort to their preparation" (Murphy \& Forsyth, 1999). As a result, the fastest, easiest and cheapest programs are emerging as major players in states across the nation. This has resulted in a decrease in entrance requirements, a decrease in courses and program hours, and in some cases a decreased focus on or absence of the internship.

Nonetheless, the argument for increasing competition has dominated recent discourse. For example, the School Administrators of Iowa Association argued, "We see becoming a competitor as perhaps the best way to get the attention of the universities as well as to meet immediate needs and overcome identified barriers such as cost, accessibility, and quality of programs" (SAI, 1997, p. I). Comments like this are troublesome, not only because they create the notion that a new program is necessarily a better program but also because they insinuate that competition is the only way to get universities to improve. In this form of discourse there is no room for collaboration and no sense of collective responsibility.

Perhaps, if there were widespread commitment to providing quality programs, then increasing competition might serve to push programs to continually improve. However, the commitment to quality, like the quality of programs in general, is variable. It is naïve to imagine that competition alone would ensure the improvement of educational leadership preparation. As noted previously, a problem as formidable and complex as this will require a major change or restructuring that extends beyond the boundaries of a preparation program.

\section{Pool of Capable and Diverse Applicants}

A study sponsored by the National Association of Elementary School Principals (NAESP) and the National Association of Secondary School Principals (NASSP) reported a steadily growing shortage of school leaders, particularly at the secondary level (Houston, 1998). This shortage, according to some could seriously hinder our school system's ability to provide educational opportunities that meet the needs of its citizens in the 21 st Century (SAI, 1998). Reasons proposed for the administrator shortage include but are not limited to: expanded expectations, responsibilities, and stressful conditions for school and school-system leaders; inadequate training; insufficient salaries and fringe benefits; and a lack of general awareness of the positive aspects of administration.

Educational leadership preparation programs have also increasingly reported a shortage of qualified applicants. The reasons for this particular shortage may parallel those identified above. They may also be related to a number of other factors. Two examples are the ongoing proliferation and expansion of school leadership programs. As noted previously, there has been a recent explosion of new administrative preparation programs both in and outside of school leadership preparation. Additionally, the size of many programs has increased substantially. Some programs, that five years ago prepared around 30 school leaders, now prepare close to 300 students for school leadership. An increase in both the number and size of programs, during a time when fewer educators are deciding to pursue a career in leadership, is likely to contribute to a program's difficulty in attracting quality students.

A related challenge is identifying what a quality applicant is. In a handful of programs, faculty, and in some cases leaders in the field, have worked to identify the types of individuals that they want to be school and school-system leaders. This is not an easy task in that not all groups will agree on characteristics and qualities. According to Cambron-McCabe (1999) the success of such endeavors depend upon first identifying our core educational purposes. She notes that identifying those purposes "is central to transforming what we do" (p. 219).

Of course part of the difficulty of finding a capable and diverse study body is related to the way that programs recruit and select their student bodies. Many programs do very little recruiting, relying instead on word-of-mouth discussions of programs by current students and graduates or geography. These methods, however, will do little more than attract the same kinds of students that most programs already serve. In contrast, programs need to actively recruit the types of individuals they and the communities they serve agree should be prepared to lead educational organizations. 
Recommendations for doing this have included direct mail campaigns and working directly with practicing educational leaders to identify individuals with the agreed upon qualities and characteristics.

A number of programs do work with public school leaders and some have found this relationship to be very helpful, others have encountered more difficulty. For example, Shakeshaft (1999) reported that "most administrators in our geographic area (unless they are Hofstra graduates) are unwilling to nominate or give us names of possible student recruits on the grounds that to do so is unethical and unfair to other administrative certification programs" (p. 241).

\section{Ongoing Program Enhancement}

There is much concern about the positions of principals and superintendents. As indicated previously, it is argued that, as currently structured, these positions are almost impossible to do successfully. In response to this concern, associations, individuals and a number of university professors have discussed the need to restructure the role of the superintendency and the principal. Of course, defining the leader of the future will be a continual process as contexts continually change. Likewise, the preparation of school leaders must also change.

The question that is frequently asked is: will they? Will educational leadership preparation programs change? Can educational leadership programs change? According to McCarthy (1999), the odds do not look promising. She wrote, "Congeniality and complacency are woven into educational administration programs and the majority of faculty do not perceive a need for the radical changes that would bring about a transformation in leadership preparation" (p. 209). However, after reviewing a number of changes in preparation, Murphy and Forsyth (1999) indicated that complacency may be on the decline. Indeed, Murphy (1999b) found that the complacency reported by McCarthy and McCarthy and Kuh (1997) is being "challenged as older members of the professoriate retire and new faculty begin to assume the reins of the profession" (p. 175). He explains that this may be attributable to the "influx of more women professors and more faculty members who are joining the professoriate from practice. There certainly appears to be more agitation for program improvement" (p. 175).

Nonetheless, it is important to consider the factors that might be contributing to complacency. For example, faculty enter educational administration programs with program structures and courses in place. Indeed in many programs, the structures predate most if not all of the faculty creating a normative understanding of "the way things work around here."

Additionally, program content and specialty areas were by and large borrowed from technical areas already existing within universities (Murphy \& Forsyth, 1999). Because these structures (e.g., evening courses held during the work week, courses offered during the university fall and spring semesters, courses held on the university campus, courses focused on traditional disciplines) and the maintenance of the status quo tend to serve the faculty and staff more so than the students, few faculty are in a position to question such structures.

Moreover, because universities generally do not support team teaching in calculating faculty load or recognize the added time and resources that structural improvements, content changes, and additional contributions to student learning would require, these changes involve commitments from faculty members that go well beyond the responsibilities of their jobs. Although, those involved in the changes are likely to feel more satisfied with their work and believe they are better serving their students, they will also be overworked and their work may go unrecognized and unrewarded within their own institutions.

Regardless, faculty have questioned traditional structures, and they have responded to the need for program improvement with extraordinary commitment. It has happened at Hofstra, at the University of Miami-Ohio, Harvard, Fordham University, the University of Utah, Wichita State University, the University of California-Berkeley, the University of Missouri-Columbia, and the University of San Diego, among others. Hofstra faculty began to focus their programs and delivery around the needs of their students. They began scheduling classes

At times more convenient for students than for faculty members-weekends, summer, earlier, later, January. ... increased the amount of time that we spending classes and in advisement. ... hold extra class meetings, we set us school-site projects that take 
considerable planning and implementation time, and we read and respond to work as many times as it takes for the student to get it to a professional level. We visit students in their schools, we try to help them find jobs.... [We] rotate the teaching of these courses so that no professor would "own a course. ... Although we have shared classes or team-taught them, it has taken a lot out of those who have done it, requiring them to learn new areas. (Shakeshaft, 1999, pp. 244-245)

Hofstra faculty are also using cohorts, which they call learning communities, and have completely restructured their content. They have been intimately engaged in program restructuring efforts. Yet in reflecting on the decade of reform following the work of the NCEEA, Shakeshaft (1999) reported mixed feelings about her program's efforts. After "a decade packed with meetings, curriculum discussions, shared ideas, strategies, and program tinkering" ... [we] have no way to guage whether or not all of our extra work is worth the effort we expend" (p. $237 \& 245$ ).

Shakeshaft (1999) has identified a common problem and a key barrier to program improvement. We do not have a lot of reliable data upon which to base our program enhancement efforts. Although many program faculty now collect data on how students are progressing through their programs and whether or not students are meeting the criteria that guide their programs, these forms of evaluation do not reveal how well students will perform once they are in the field. We have yet to develop a method for determining whether or not the graduates of educational leadership programs will be successful. Until we have a process for determining whether or not educational leadership preparation has any of the impacts that we hope for them, it is not likely that we will have adequate information to engage in effective program development. And without evidence of success, faculty may not be willing to sustain the extra work many program reforms require.

\section{Program Content and the Work of School Leaders}

The disconnect between what is taught in many university preparation programs and what practitioners need to be able to do in their schools and school districts is frequently cited among stakeholders in educational leadership preparation (Cambron-McCabe, 1999).

At the dawn of this millennium, the challenges for secondary schools in the United States include principals trained to be managers rather than instructional leaders, and a dramatic shortage of qualified candidates willing to take on the principalship. (Phi Delta Kappan, Tirozzi, February 2001, p. 435)

It is our belief that this criticism is related to the concern raised by Shakeshaft (1999) that we do not have reliable data upon which to base our programmatic efforts. There is certain to be a disconnect, regardless of how well a program's content is aligned to national standards, if faculty have no way of accurately measuring how well they are preparing leaders for the field. Many programs have tried to overcome this barrier by creating practitioner advisory boards, having students create portfolios reflecting their growth, and sending out surveys to graduates and their employers a year or more after receiving the graduates were licensed. However, this type of data has been considered inadequate (e.g., not comprehensive enough, not rigorous enough) for the purposes of program evaluation and change.

Nonetheless, and as noted above, programs are engaging in improvement efforts, and there is a concerted push to increase focus on the practice dimension of the profession. To illustrate, in 1996, Murphy (1999b) surveyed the chairs of educational administration programs about program change. These leaders reported change in recruitment, selection, monitoring/assessing progress, clinical experiences, program content, pedagogy, practitioner involvement in delivery, mix of students, and departmental mission/agenda. Most of the changes aligned with the recommendations of the NCEEA (1987) and the National Policy Board (1989), both of which advocated a closer relationship with practice. Many also address criticisms that

Traditional principal preparation programs offered by colleges and universities are disconnected from the daily realities and needs of schools. Principal training seldom is anchored in hands-on leadership experience in real schools, where principals-in-training might learn valuable lessons in shaping instructional practice, sharing and delegating authority, nurturing leadership ability among school faculty and staff, and exercising community and visionary leadership. (IEL, 2000, p. 9) 
Several other indicators point to an increasing focus on the practice of school leadership. For example, in the 1990s, educational administration programs hired more faculty with administrative experience, "reflecting a change in views toward the value of such experience" (McCarthy, 1999, p. 202). More programs are questioning the appropriateness of the dissertation as a capstone experience for those preparing for leadership positions (Skakeshaft, 1999). Additionally, if one considers the research presented at UCEA and AERA's annual conventions over the past ten years, one will find that more researchers are focusing their work on teaching, learning, and social justice; more are attempting to link theory to practice; and more faculty are writing about the preparation of school administrators. Finally, Murphy (1999b) found that program change and development was a consistent theme in the educational leadership programs he surveyed.

In some cases, this was reflected in the revision of courses to make them more current or to bring them into line with emerging reform themes. More often, it was seen in more molar changes; that is, more comprehensive overhaul of programs. (Murphy, 1999b, p. 179) Yet, while there have been certain improvements in the preparation of school leaders over the past decade, it is not yet possible to determine how widespread these initiatives are, and the effects of these initiatives need to be evaluated to determine if they are supporting the effective preparation of educational leaders.

\section{Licensure and Accreditation}

Perhaps the most profound influence on educational administration preparation programs has been state licensure agencies. According to McCarthy (1999) "the initial growth of university programs was precipitated by such licensure requirements. State governments have preferred to monitor individuals through licenses, which in turn influences the content of preparation programs, rather than by imposing mandates directly on universities" (p. 120). Most states currently have licensure requirements for school and school system leaders; only a few do not. However, over the last year a number of states have weakened their licensure requirements. At the 2000 NCPEA conference, Cecil Miskel argued that there was a strong link between weakening state licensure requirements and the ability of educational leadership programs to prepare effective leaders. He argued that strong and quality state licensure requirements are necessary to ensure that all programs adequately prepare school and school-system leaders. State licensure can play an important function in ensuring that only well prepared and qualified individuals are provided licenses to lead. Some question, however, whether or not increased state control (or "the regulation of the profession by non-educators") is a wise move (Horn, 2001,p. 2). In describing the situation in Texas, Horn argued that accountability, which in and of itself is not bad, severely limits preparation program autonomy. Specifically, he argued that program decisions are often made and constrained by the state licensure exam their students will take rather than by what professors, practicing administrators and leadership scholarship indicate comprises quality preparation. Horn, similar to other critics of standardized measures, expressed skepticism about the ability of a one-point-in-time pencil and paper examination to accurately measure one's ability to lead.

Part of Horn's skepticism, it seems, is based on the fact that "regulatory agencies make the basic policy decisions, and the educational preparation programs must react to them. ... higher education professors and administrators have minimal participation" $(2001, \mathrm{p} .2)$. The lack of participation of professors in setting policy on leadership licensure is reflective of the professoriate's lack of participation in state and national conversations about leadership preparation in general. Although, professors discuss and debate preparation approaches and standards at higher education meetings, like the AERA, UCEA, and NCPEA conventions, few have been involved in national discussions on leadership and leadership preparation (Olson, 2000). Professors of school leadership can be important resources for information on the state of school leadership and school leadership preparation. After all, it is their life work, their area of specialization. Yet university professors, by and large, are not the preferred sources for information and advice on school leadership policy and discourse. Moreover, "many educational leadership professors are still operating as they were taught 30 years ago that school leaders should not be politically active or involved. Thus, they are hesitant to be proactive on any issue that has political overtones" 
(Shipman, 2001). According to Shipman, licensure and certification agencies provide opportunities for those effected to impact policy making and to make implementation decisions within their own environments.

In many states, licensure mandates have been strongly influenced by a set of standards created by the Interstate School Leaders Licensure Consortium (ISSLC). Quite recently, these standards have been incorporated into state and national accreditation. Close to 40 states in the nation are either members of ISSLC or have adopted the ISSLC standards for school leadership. These standards are typically used by state agencies to guide their review and accreditation of university leadership preparation. Similarly the Educational Leadership Licensure Consortium (ELLC), which performs educational leadership program reviews for the National Council for the Accreditation of Teacher Education (NCATE), has recently adopted the ISSLC standards for their use. Some program leaders see the growing uniformity of program standards as a positive development. Many programs are reviewed by several different agencies and organizations (e.g., NCATE, TEAC, state departments, Southern Association of Colleges and Schools, and the North Central Association). Thus, having a single set of standards is considered a helpful development. Some skepticism remains, however. Specifically, the ISSLC standards themselves have been questioned and debated with regard to their comprehensiveness and their appropriateness for all levels of educational leadership, and the implementation of the standards through program review has been criticized.

\section{Centering Our Profession on Children}

In an invited address at the 1999 AERA meeting in Montreal, ${ }^{4}$ Murphy called for a "new center of gravity" for educational administration. Murphy (1999a) suggested three themes that could serve as centers: democractic schooling, school improvement, and social justice. We believe that the profession need not choose among these three, because at the core of each is the children we are charged with educating and nurturing. We must have as a foundation for all of our actions a commitment to the development of leaders who can lead schools that are high performing for all children, regardless of race, ethnicity, gender, class, etc. As a profession, we have historically failed millions of children. It is time that we refocus our efforts on the true center of our profession: children.

Centering our profession and our work on children, their education and their development may seem too obvious, and yet many have argued that as a profession we appear to have lost sight of this purpose (Achilles \& Mitchel, 2001; Cambron-McCabe 1999). The way our schools our organized, the way our teachers practice, the way our leaders supervise their faculty, they way our teachers and leaders are prepared must all focus upon the essence of our responsibility: to ensure that all children learn at high levels. According to Cambron-McCabe, recognizing children as the center of our profession would mean drastic changes for our profession. With regard to leadership preparation, it would mean that the skills and knowledge administrators need to redesign schools for widespread student success are vastly different from the program content and understandings provided by most of today's educational administration programs. More broadly, centering our profession on children and their learning will require that all educational stakeholders think and act differently than we have in the past.

\section{Addressing the Improvement of Educational Leadership in the Current and Future Context}

\footnotetext{
"We have reached the point where the first duty of intelligent men is to restate the obvious." - George Orwell.
}

To this point, we have made the case that a thorough and comprehensive examination of leadership preparation programs in their current context is appropriate and necessary. Decreased institutional support, the stronger presence of state licensure mandates, and federal and state government sponsored initiatives designed to prepare school leaders coupled with proposals in some states for alternative licensure for school administrators, among other developments has left 
many university programs in precarious and untenable positions. However, the rhetoric of dissatisfaction typically smooths over or ignores these factors and/or oversimplifies the limitations of leadership preparation programs to produce the quantity and quality of leaders needed for today's schools. We understand the need for change; the need for change is not at issue here. Our concern is that the approach we take to reform be informed, comprehensive, and represent a collective effort.

Unfortunately, many current proposals and approaches (e.g., competition, state control, etc.,) to the "leadership crisis" are narrow, ill informed, and will not address the issue in a holistic or systematic fashion (Young \& Petersen, 2000). In commenting on the discourse of competition, for example, Murphy (1999a) noted "Contrary to economic theory, there appears to be a widespread feeling that this "competition" is lowering standards across educational administration programs in general and in the traditional quality institutions in particular" (p. 33). The history of educational administration is full of attempts to redesign administrator preparation programs ${ }^{5}$ (Björk \& Ginsberg, 1995; Forsyth, 1992; 1999; Jacobson, Emihovich, Helfrich, Petrie, \& Stevenson, 1998; Griffiths, Stout, \& Forsyth, 1988; McCarthy, Kuh, Newell, \& Iacona, 1988; Murphy, 1992,1993,1999b; Pitner, 1988; Short, 1997). Some have been more successful than others (Björk \& Ginsberg, 1995), but few if any have reflected the interdependence and comprehensiveness that substantive change will require.

Part of the dilemma we face may be a result of the lack of a shared vision (Forsyth, 1992), common scaffolding (Murphy, 1999a), or clear working assumptions that inform the work of educational leadership faculty (Cambron-McCabe, 1994) and other educational stakeholders. These contrasts make it difficult to respond collectively. These contrasts also make evident the need for stakeholders in leadership preparation to come together in an effort to develop shared understandings and common goals with regard to the future of leadership preparation.

We are well aware that the preparation and development of school leaders is a special kind of business. Although there are a variety of programs and settings, most would agree that the underlying goal and orientation of leader preparation is the development of competent compassionate and pedagogically oriented leaders committed to the successful education of every child. The call for a re-focusing of the preparation of school administrators by Boyd (1983) is even more appropriate today than eighteen years ago. "School management and the preparation of school administrators need to be vigorously redirected toward the enhancement of the outcomes of schooling for children." (p.4). Education is the single common ground and hope left in an increasingly splintered society and the success of children is at the very center of the leadership profession. What has become increasingly evident in the last thirty years of the $20^{\text {th }}$ Century, is that school leaders cannot ensure the success of all children alone; likewise the preparation of educational leaders must be approached collaboratively. Universities that prepare educational leaders, professional organizations, and field-based practitioners need each other in order to achieve this goal. Yet, universities, professional organizations, policy makers, school administrators, and the private sector have not employed their collective potential to improve the profession of school administration.

Given the numerous calls for reform, the question remains, "If we have not instituted significant reforms over a decade how can we expect substantive changes in the near future?" (Clark, 1999, p. 218). In this section, we offer the metaphor of a league as a conceptual framework for a new approach in the preparation of educational leaders. Metaphors are powerful tools in making the ambiguous unequivocal, and for simplifying our understanding of complex images (Morgan, 1997). In terms of school administration, Sergiovanni (1991) suggests that in order to develop a new leadership practice we must change our metaphors. We believe the required acknowledgment of interdependence among key-stakeholders articulated in the orientation of a league might provide the necessary working relationships to accomplish systemic change in the preparation of school leaders.

The League

Bob Costas' recent book Fair Ball $(2000)$ provides principles he believes will return fiscal stability to professional baseball and with it the public's interest. One could argue that the 
preparation of educational leaders is not even remotely comparable to a discussion on the economics of professional baseball. However, in his analysis, Costas offers a metaphor that has application to our discussion here. He removes the superficial veil of open and free-market competition between teams and discusses the underlying role and interdependence of a league. "In a league, all members compete for the same thing and seek the ideal outcome." (Costas, 2000, p. 46). He makes the case that in a league, each franchise is not independent, but interdependent. " $A$ league is not like 30 restaurants on a busy street and each owner has no real concern about the success of the other 29. Properly understood, it is less like 30 different restaurants and much more like 30 franchises within a single restaurant chain" (p.46). They are competitive, they want the prestige of a five-star rating, but they are not trying to put each other out of business. Each unit (franchise) is dependent on the success of the other. Although the responsibility of each franchise is to win championships, they must also maintain an obligation to the welfare of the league as a whole.

While the only lasting definition of success in professional baseball may be a World Series championship, in schools, the only lasting definition of success is the achievement of children. The underlying goal and orientation of leader preparation is the development of competent, compassionate, and pedagogically oriented leaders committed to the successful education of every child. In almost any other field, it would be normal, even desirable, for the weaker and less capable organizations to fall by the way side. But this is not the natural occurrence in public education, where it could reasonably be argued that the system of education is only as healthy as its weakest schools and programs. When children are not successful, it reflects poorly on the public image of the profession and is contrary to the goals and mission of education.

A similar case can be made for programs that prepare educational leaders. Although studies have called for a reduction in programs that prepare school leaders (Griffiths, Stouts, \& Forsyth, 1998), this has not happened. In fact, fueled by federal and state initiatives, practitioner-oriented professional organizations, foundation supported initiatives, and private enterprises (Brown, 2000), we see our field besieged with an increasing number of programs. The rhetoric in the current environment is often fractionalized, conflicting, and oriented toward a stance of competition. Frequently, leader practitioners and professional organizations maintain a critical stance toward university preparation programs, and universities have a difficult time articulating a convincing argument of their essential role in the preparation of school leaders. What is evident is that no department of educational leadership, professional organization, or private enterprise is prepared to offer an appropriate program of study independently (Clark, 1999; McCarthy \& Kuh, 1997).

The metaphor of school leader preparation as a league will require that stakeholders take a different approach to educational leadership preparation. Operating under this metaphor, individual faculty, departments of educational leadership, academic organizations, professional organizations, and field-based administrators concerned with the development of educational leaders must recognize their collective responsibility for forming an association or alliance with the goal of preparing competent, compassionate, and pedagogically oriented leaders. (See Figure 1) 


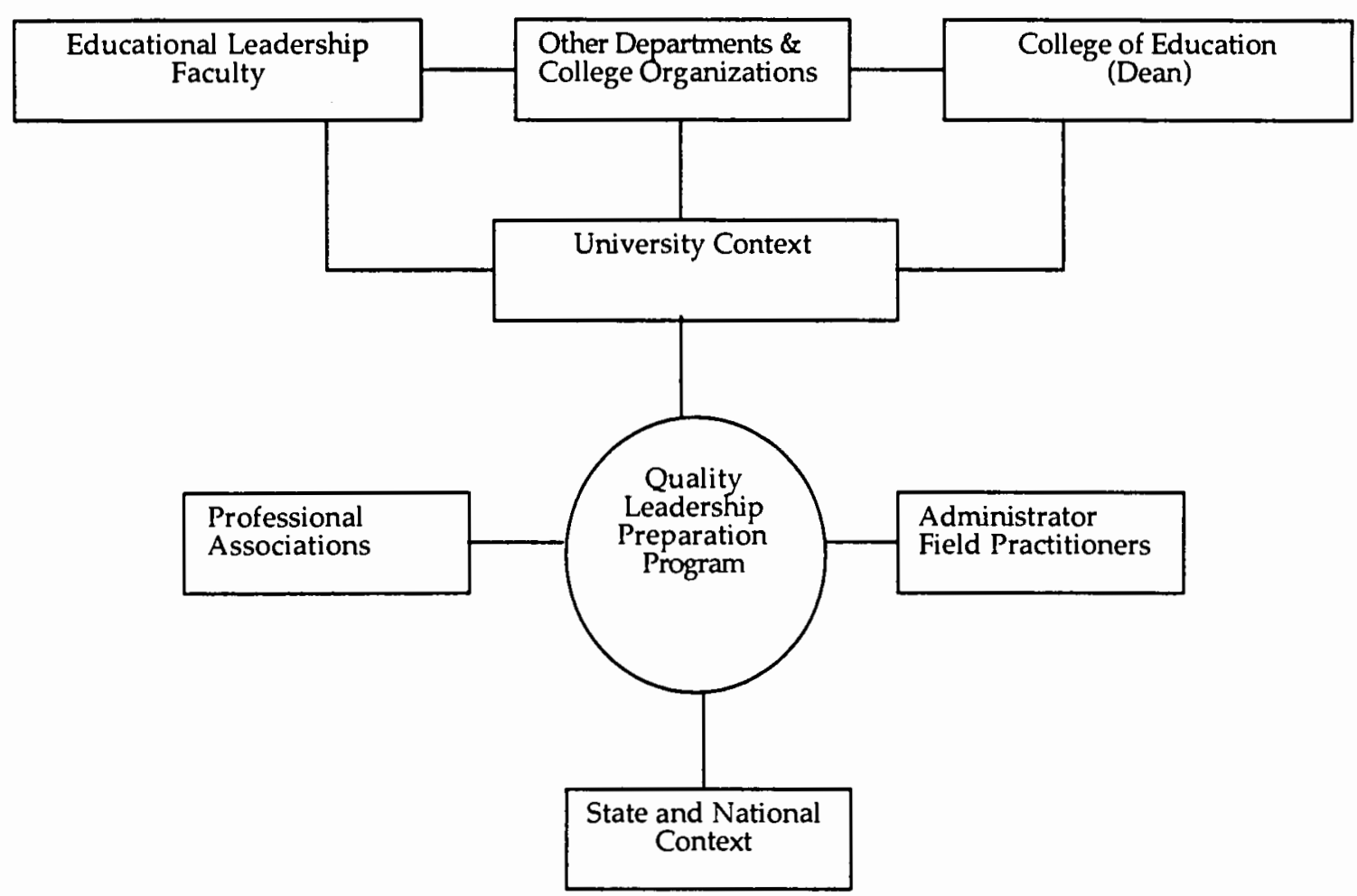

Figure 1: The League of Key-Stakeholders Contributing to the Quality Preparation of Educational Leaders

The question we will consider now is how would educational leadership preparation change, if these perspectives were taken seriously? If practitioners, professional associations, educational leadership faculty, university administrators, accrediting agencies, licensure boards, and every other key stakeholder were to take these ideas seriously and were to interact interdependently, as an educational administration preparation league, what would they do differently? How would these separate but interdependent groups collectively work to prepare educational leaders?

\section{The Leadership Department}

Professors teach about the change process and the importance of information on issues of organizational context, resources, and need before undertaking major change. "There is evidence that some programs do require radical change, yet the creation of a dynamic, effective setting for the study of schools and the preparation of school administrators is not a chance happening ... The preparation of professionals requires constant adjustment to changing technology and to evolving notions of best practice" (Griffiths, Stout, \& Forsyth, 1988, p. 300). We argue that administrator preparation programs must facilitate changes in everything from the planned recruitment, selection, and retention of diverse students and faculty (Griffiths et. al, 1988; Murphy, 1999a), program content and curriculum (Clark, 1999; Murphy, 1999a), and on going professional development offered to faculty, to the establishment of an ethic of collaboration (Cambron-McCabe, 1999).

Department Faculty. Professors in departments of educational leadership contribute to the development of future leaders in three significant ways: as scholars, teachers, and mentors. While the nature of our research approaches have been criticized for failure to inform the work of schools (Clark, 1997; Starratt \& Foster, 1994), we are measured, promoted, and expected to become prolific 
scholars. Herein lies a dilemma of our profession. Previous observers have indicated that a fundamental responsibility of faculty in departments of educational leadership is the establishment and fostering of a close working relationships between the university and the world of practice. It is agreed that faculty must be actively involved in working for school improvements, designing and evaluating field-based research, and recruiting and monitoring highly qualified candidates for school leadership (Griffiths et. al, 1988).

Given the nature of our profession, educational administration faculty are often torn in their responsibilities for success in the university setting with the need to establish strong professional ties with the field of practice. We contend that a well-planned collaborative undertaking, involving discussion and planning by college and university administrators, faculty, and field practitioners, will facilitate a clearer understanding of the dual purposes in departments of educational leadership. Such an effort may result in positive changes in promotion and tenure requirements that accommodate faculty's competing responsibilities. "Ultimately, roles in departments of educational administration need to be differentiated by both scholarly focus and responsibility for the many aspects of a professional preparation program" (Griffiths, et. al., 1988, p. 300).

In addition to performing this critical linkage, faculty must provide outstanding classroom instruction and career nurturance in the preparation of practitioners (Clark, 1999; Van Meter, 1999). In their roles as teacher and advisor, faculty and departments of educational administration, must be in a position to expose students to appropriate and relevant programs of study with a clear and predominant focus on the issues that influence student success. For example, Dryfoos (1994) points out that as a result of a deteriorating social environment many children face substantial barriers to growing into responsible adults - substance abuse, teen pregnancy, delinquency, and depression. Designing programs that prepare educators to lead in our current and future context, therefore, must ensure that, just as no leader lacks expertise in curriculum and instruction, no leader is unprepared to support the education of all children regardless of their race, class, etc. Meeting this challenge will require a change in course offerings and will fuel the debate on the knowledge base and activities of educational administrators (Murphy, 1999a).

Related Departments. Within our preparation program planning, we should consider the contributions that other fields that focus on schooling and children can make to the preparation of educational leaders. Like Clark (1999), a number of scholars have declared that "no department of educational leadership is prepared to offer an appropriate program of study on its own. ... outstanding programs in educational leadership are rooted in much more complicated fields of study" (p. 231). In program planning, it has been suggested that faculty build ties with departments of curriculum and instruction, schools of business, and schools of social work, to name only a few.

While most departments of educational administration offer program courses designed toward traditional paradigms of managerial practice (e.g., organizational theory, policy, law, and finance), we believe that not only should a school leaders have expertise in curriculum and instruction (Clark, 1999; Van Meter, 1999), but they should also have knowledge and course work in areas that will inform their practice and permit them to more successfully respond to the current needs of children and their families. Although "we cannot do everything in the abbreviated time available to us in graduate preparation programs, we can do much more than we are doing" (Clark. p. 232).

Department Chair. Department chairs play a strategic role in the faculty and department's success in preparing and designing quality leadership programs. Scholars who reluctantly serve as chairpersons are unlikely to foster the type of environment necessary for the study of schools and the preparation of school administrators (Griffiths, et. al., 1988; Murphy, I999b). The department chair must accommodate the needs, expertise, and dualistic role requirements of education leadership faculty (Gmelch \& Miskin, 1995). What cannot be underestimated or receive only cursory attention is the department chair's role in recruiting and selecting diverse students and faculty, providing opportunities for the professional development of faculty, securing resources, and establishing collaborative networks with the College Dean and other units within the college. Department chairs are able to promote the expertise in leadership and organizational theory residing within the preparation program in context with larger campus efforts. Building connecting points between the preparation program, the college, and the larger university community will heighten the 
value of the program with other units within the college as well as with policy makers and academic program leaders in the larger university setting. These interactions should facilitate the development of critical relationships and establish a "learning community" that is aware of the dualistic nature, efforts, and goals of departments of educational leadership. Through the establishment of these relationships traditional orientations of university faculty (e.g., tenure and promotion) may be clearly presented, understood, and redressed. The construction of these linkages will also permit collaboration with other units around significant issues facing schools and the preparation of educational leaders.

\section{The College Dean}

While continuous changes and unpredictability create a complex environment for these managers of academic affairs, deans play a strategic role in the establishment of standards and policies for the college. The dean provides the environment for the promotion of excellence in teaching, research, and professional service. In 1987, The National Commission on Excellence in Educational Administration report advocated two primary responsibilities for college deans. The first was the provision of adequate funding for and staffing of educational administration programs, and the second, was a change in the reward structure for professors to one that recognizes other activities in addition to traditional scholarship. While we would continue to advocate for these responsibilities, we believe that another, and perhaps more fundamental role is that of liaison between the academic departments, the university, neighboring institutions, and state, national, and professional organizations.

We contend that the department chair and college dean should act as liaisons between the department and the university and help build a recognition within the university of the dualistic focus of leadership preparation programs (i.e., practice and scholarship). This is particularly important in the modern research university. Elevating the awareness of the campus community in relation to faculty expertise is also important. Moreover, understanding the complexity of preparing professional educators and educational leaders, college of education deans are in a ideal position to demonstrate the program's role in the university's broader mission (i.e., beyond scholarship) and their similarities with programs in other professional schools (e.g., school of architecture, school of law, school of business, school of medicine) (Griffiths et. al, 1988). Promotion of the program and its goals within the context of the university mission may result in increased support and regard from central administration, the acquisition of scarce resources, and increased understanding of the importance of leadership preparation. Such activities may also lead to other developments. For example, when such efforts were employed at the University of Missouri, it resulted in university system cooperation to provide exceptional programs in educational leadership throughout the state.

Moreover, the dean, as liaison, should foster conversations with stakeholders external to the university in an effort to increase recognition and valuing of the dual purposes of educational leadership programs. Because of their familiarity with the program's goals and objectives, they would also understand that the current context of school leadership preparation is often impacted by increased competition from both neighboring institutions and privately financed groups like Sylvan, and this competitive tension has the potential to disconnect programs and practice. In many cases, this competition is rooted in credit hour and time-to-completion, not in challenging traditional graduate programs or expectations of job performance. The role of the dean in these instances should be to support program quality. This can be done in a number of ways, such as assisting program faculty in the recruitment of capable and diverse candidates; ensuring that programs have the resources to maintain quality, creating and nurturing connections between the leadership preparation programs in the state, state and national organizations (e.g., professional, credentialing, research, foundations, and other colleges), and state education, licensure, and professional development agencies.

\section{The University}

As noted in a previous section, the loose coupling of universities, particularly the modern research university, makes it difficult for university administrators outside of the College of Education to know much about educational leadership programs. It is important that program 
faculty understand this barrier and take proactive steps to ensure their program is well recognized and well supported. First, educational leadership preparation programs have an obligation to acknowledge the university's overall mission and to determine how their program compliments that mission. Faculty must understand how their program focus, mission, and vision is situated with regard to the larger university strategic plan and then articulate this information to university officials. We contend that this form of mind work must precede any form of advocacy upon the part of the department for resources.

Likewise university administrators must recognize and seek to understand the dual role of educational leadership programs. If universities wish to continue educational leadership preparation then they have a responsibility to ensure their programs are of high quality. Although few university administrators have been known to focus their attention keenly upon the needs of educational leadership programs, there have been notable exceptions. For example, at the University of Texas-Pan American, the president and provost took a strong interest in educational leadership. As a result, the program and administration have established an ongoing line of communication and have worked to develop mutually beneficial program and university policies.

Although university administrators should, without prompting, take an active interest in educational leadership, the promotion of the department within the university context is essential. Faculty must work with practitioners (preferably a formal advisory board) and the college dean to determine what forms of support the department requires in order to effectively fulfill its responsibility to the field. They must also determine whether departures from traditionally university-sanctioned practices are needed (e.g., from changes in promotion and tenure to providing preparation outside of the traditional semester course format) (Owens \& Steinhoff, 1992). In his review of the nature of many recent reform efforts, Van Meter (1999) noted that few reform efforts in educational administration seriously challenge traditional graduate school policies and requirements adopted by most universities. However, substantive change in educational leadership preparation will require similarly considerable changes in university norms.

However, McCarthy (1999) suggested that changes in university norms will require more than faculty advocacy. Rather, "such changes are unlikely without additional leverage from outside the field as well as support from national groups, such as the NPBEA and professional associations" (p. 205). If, as a profession, we believe that programs should include more faculty with practical orientations and dedicate more time to collaborating with colleagues and practitioners, devising growth plans for individual students, conducting applied or action research, monitoring student progress, team-teaching courses, providing meaningful internship experiences, and observing students in their schools, then as a profession we must take collective responsibility for influencing universities to support these initiatives.

\section{Professional Associations}

We have advocated, along with other observers, that only through a collaborative effort will our profession have the capacity to address issues surrounding the preparation of school leaders that promote the success of all students. We feel that one example of the formation of associations allied for common action toward this goal is reflected in the efforts and initiatives conducted by the National Policy Board on Educational Administration (NPBEA). This reform agent has actively sought, through collaborative efforts, to strengthen the preparation of school administrators and the robustness of departments of educational leadership (Murphy, 1999a).

In 1987, Members of NCEEA felt that the major practitioner and professor-oriented organizations for school administrators had not tapped into their potential to improve the profession (Griffiths et. al, 1988). A key implementing recommendation of the Commission was the establishment of a National Policy Board for Educational Administration (Thomson, 1999). As McCarthy (1999) points out, "The creation of this Board was a milestone event because it brought together the major professional associations interested in improving school leadership after they had drifted apart for more than two decades" (p. 122). Following its inception, the NPBEA sponsored a series of national forums, projects, and publications focused on the establishment of compatible standards and assessments for school administrators and has attempted to influence leadership preparation programs (McCarthy, 1999; Thomson, 1999). NPBEA initiatives include 
the development of standards for leadership preparation program review in collaboration with NCATE; the development of six national licensure standards for administrators (ISLLC) in collaboration with the CCSSO; as well as the publication and national distribution of commissioned monographs focusing the quality of the profession. These efforts have stimulated thought and dialogue among all of its key stakeholders.

Although in recent years the NPBEA has been less active and its efforts have been debated with regard to their ability to transform leadership preparation programs, the NPBEA's work provides an exceptional example of collaboration. The NPBEA, which is made up of several different stakeholder groups in educational leadership preparation, provides an opportunity for those stakeholders to discuss and collaborate on critical issues in the field. Such alliances, developed around a common goal, are needed to move our profession in a direction that addresses issues of practice, knowledge, and quality. The present context provides a significant opportunity for NPBEA and its individual member organizations to collaboratively establish and commit to a reform agenda for the benefit of the profession and our nation's children.

\section{Field Practitioners}

As the roles and responsibilities of school leaders become more extensive and it becomes evident that schools alone cannot address the societal changes affecting children, many administrators find themselves building partnerships or collaboratives with multiple groups, including child care, social, health, and community agencies (Cibulka \& Kritek, 1996 as cited in Cambron-McCabe, 1999). These types of collaborative initiatives should also involve leadership preparation programs. Often times when universities speak of forming partnerships and involving students in problems of practice, they are referring to traditional ideas of clinical experiences in elementary schools, secondary schools, or district offices. Yet, the complex responsibilities faced by school leaders continue to pose challenges not only to practitioners but also to the programs that prepare them.

While there seems to be universal agreement regarding the importance of connecting preparation programs to practice (Cambron-McCabe, 1999), few institutions actually implement programs that are mutually and collaboratively developed and that demonstrate organizational commitment from all parties (Fusarelli \& Smith, 1999). Reporting on several studies that examined practice-based programs, Hart and Pounder (1999) made a case for the importance of a strong and vibrant collaborative relationship with field practitioners as an essential element in any pre-service administrator's learning experiences. Other scholars have concluded that field-university partnerships offer aspiring administrators as well as cooperating programs considerable benefits (Leithwood \& Steinbach, 1995; Milstein, Bobroff, \& Restine, 1991). Educational leadership programs at several well-respected universities have answered calls for an expansion of the involvement of field practitioners (UCEA Review, 2000; 2001). For example, Fordham University's Visionary, Instructional, \& Administration Program has included district and school leaders from the outset in the design of the program content and clinical experiences. Participating districts also provide financial support and mentoring of students in the program. At the University of Missouri-Columbia they have incorporated cohort formats $\&$ forged strong linkages with school districts, institutions of higher education, and other state agencies throughout the state in both their specialist and Ed.D. programs.

These examples have highlighted only positive illustrations of collaboration between practitioners and university programs. However,

practitioner participation takes on many forms, on the weak end of the spectrum groups of practitioners get together from time to time...The strong end of the continuum is characterized by collaborative partnerships... They allow school administrators to assume more active roles in program development, working collaboratively with university faculty to design and build the infrastructure for preparation programs rather than simply evaluations completed training models. (Murphy, 1999b, p. 184)

If programs are to be effective, practitioners must be intimately involved in preparation. Practitioners should assist in program development, student recruitment and selection, course delivery, mentoring, internship supervision, and student evaluation. 
It appears that educational leadership units clearly understand the importance of connections with the field (e.g., recent hiring practices of faculty with administrative experience, increased attention given to problems of practice within university curriculum). Unfortunately, and as noted in a previous section, while educational leadership faculty members are taking steps to become more connected with the field, little evidence exists that universities, especially Research I institutions, are embracing the idea of faculty engaging in outreach activities and applied research (McCarthy, 1999). Therein lies our dilemma. The field connection is essential but the development and maintenance of long-term collaborative partnerships requires tremendous faculty resources and raises contentious reward questions (Cambron-McCabe, 1999). Thus in addition to the roles administrative field practitioners must play in preparing competent, compassionate, child-centered administrators, their assistance will also be required in raising the awareness of the university community about the critical importance of linkages between the university preparation programs and field.

\section{State \& National Contexts}

Educational leadership has become a prominent issue at both the state and national level. Although programs for school leaders remain the primary responsibility of universities, there have been a number of government initiatives designed to impact leadership preparation. For example, some states (e.g., Texas) have created alternatives to university preparation for school leadership. Other states (e.g., Ohio) have undertaken extensive evaluations of educational leadership programs, resulting in the elimination of some programs. Moreover "a few, such as North Carolina, are making significant fiscal investments in improving preparation... . [and] about half of the states [were] involved in a consortium to create interstate licensure standards" (McCarthy, 1999, p. 208).

Similarly, foundations, like Danforth, have supported initiatives across the country focused on improving the practice and preparation of school and school system leaders (Cambron-McCabe, 1999; McCarthy, 1999; Milstein, 1993). National organizations, like NPBEA and UCEA, have also forwarded reform agendas and worked to enhance the preparation of educational leaders. Program quality is also a concern of NCATE, TEAC, and other accreditation organizations. Moreover, the development of the ISSLC standards has had significant implications for preparation programs (McCarthy, 1999).

Although, some of these and other initiatives have been considered successful, others are believed to have fallen short of their goals. McCarthy (1999) asserts that "it is not yet possible. . . to determine how widespread the impact of these initiatives has been and whether leadership preparation has actually improved" (p. 209). Indeed, there has been no comprehensive evaluation of these initiatives to date.

It is interesting to note that most new reform practices have been developed outside of the university. These programs have not involved universities in their inception or policy implementation (McCarthy, 1999). Although change is rarely effective when reforms are created without the input of those whom the reform will ultimately effect, this exclusion is likely due to the common sentiment that university educational leadership programs are not interested in changing. Thus, "the press is clearly toward external control mechanisms [e.g., competition] as the stimulus to drive educational improvement" (Clark, 1999, p.233).

We, however, are not convinced that educational leadership faculty are disinterested in improving their programs. Rather, we have observed a great deal of support for and effort dedicated to program improvement. Moreover, most educational leadership programs, whether they are supporters of change or not, are engaged in an ongoing process of change. According to CambronMcCabe (1999)

The complacency that McCarthy and Kuh (1997) identified could be the result of a product orientation. We have all experienced revision processes to meet new standards. The familiar pattern is that departments make the required adjustments and check off each mandate. At the end of the process, a new program is adopted, and faculty move on to other priorities. Over the past decade, we have made some program changes, presumably fixing the problems identified by our critics. (p. 225)

What Cambron-McCabe has described is a rather reactive process of reform. Reforms often come 
to programs for implementation rather than faculty proactively initiating or generating reforms for their own programs. This is unfortunate, given the professional and contextual knowledge that professors have of the field and their programs respectively. "The reputational status of education leadership programs on university campuses tends to make them vulnerable to outside pressures for reform rather than reliance on professional norms generated from within the profession" (Glasman, Cibulka \& Ashby, 2001, p.3).

It is our position that key to the success of any effort to positively and substantively change the preparation of school and school-system leaders depends upon the collaboration of key stakeholders. Without collaboration serious information gaps and disconnections between reform designers and implementers will detrimentally impact the quality of the reform and its implementation. Our approach to supporting positive change must be comprehensive and indicative of the interdependent nature of our work and our actions. As noted previously, no single organization, group, or individual can create the kind of changes for leadership preparation that are needed. Substantive change requires collaboration.

\section{Summary}

Viewing the preparation of educational leaders through the metaphor of a league elucidates the limitations of independent or loosely coupled reform efforts. Costas (2000) reminds us that the success of the league members in achieving their common goal depends upon both quality of performance and quality of collaboration. In the field of educational administration there have been few points in our history when we have sought change through collaboration. Thus, there is no precedent for the interdependent conduct that is currently needed.

Although it would be naïve to suggest, given the complexity of our current complex circumstances, that implementation of the linkages proposed in this model will immediately "solve" the problems facing school leadership preparation, it is our belief that collaboration is essential to our eventual success. Only through partnerships with key-stakeholders can we establish a clear and common agenda, and only through interdependent efforts can we achieve our common goal--the development of competent, compassionate, and pedagogically oriented leaders committed to the successful education of every child. We would argue that administrative aspirants, preparation programs, universities, professional organizations, and schools would benefit equally from the type of alliance we have discussed here.

\section{Conclusion}

Educational leadership preparation must meet the needs of our current and future schools. We can tolerate nothing less than quality programs that prepare leaders to support the education of all children. Ultimately, this is our common goal--high quality education for all children. This is something that teachers, principals, central office personnel, educational administration professors, researchers, regional service center personnel, Department of Education personnel, and other stakeholders have in common--we are all working, ultimately, for the benefit of the children in our schools, school districts, regions, and states.

What we have suggested in this manuscript is that if we are to realize the goal of ensuring educational excellence and equity for all children, we must first recognize that our work is fundamentally interdependent. None of our organizational or individual activities operate within a vacuum. Rather, we are constantly impacting each other and the preparation of school leaders.

Second, we must rethink what we do to ensure that it contributes to rather than detracts from quality preparation. This will require that we come together, seek a mutual and complex understanding of our context and the stakeholders that work within it, build common ground and shared goals, and work collaboratively toward their realization. Each of these steps is essential.

- We must recognize our interdependency.

- We must come together.

- We must seek understanding.

- We must build common ground.

- We must work collaboratively.

Like many issues confronting our nation today, the challenges facing educational leadership are 
complex and interconnected. It is important that we approach them in this way. Otherwise we will fall victim to misunderstanding, certain disillusionment, and the folly of shifting blame.

Our conversations and work related to reforming leadership preparation may focus too frequently on identifying structures, content, or methods of delivery for preparing educational leaders, when what we need is a commitment as a field to an ongoing collaborative effort. We have before us an opportunity to critically examine and discuss the complex factors and interconnections that support and detract from quality leadership preparation and to design recommendations for supporting positive substantive change in leadership preparation. Given our current climate these efforts are truly important. Furthermore, it is our collective responsibility. No other collective of professionals knows more about school leadership training than we do, and no other group, in our perception, cares as much about the development and delivery of quality school leadership

preparation for the benefit of all children. At this juncture, then, we need to move beyond individual and group interests to consider issues in which we are mutually invested, and we must create and implement an organized and collective agenda for the improvement of educational leadership preparation. 


\section{References}

Björk , L. G., \& Ginsberg, R. (1995, February). Principles of reform and reforming principal training: A theoretical perspective. Educational Administration Quarterly, 3I(1), 11-37.

Boyd, W. L. (1983, March). What school administrators do and don't do: Implications for effective schools. The Canadian Administrator, 22(6). 1-4.

Brown, D. H. (, 2000, September 20). New Leaders for New Schools. Education Week, 20, (3), p. 6

Campbell, R. F., Fleming, T., Newell, L., \& Bennion, J. W. (1987). A history of thought and practice in educational administration. New York: Teachers College Press.

Cambron-Mc-Cabe, N. H. (1999). Confronting fundamental transformation of leadership preparation. In J. Murphy, \& P. B. Forsyth (Eds.), Educational administration: A decade of reform (pp. 217-227). Thousand Oaks, CA: Corwin Press Inc.

Capper, C. (Ed.). (1993). Educational administration in a pluralistic society. Albany, NY: SUNY.

Cibulka, J. G., \& Kritek, W. J. (Eds.). (1996). Coordination among schools, families, and communities: Prospects for educational reform. Albany, NY: SUNY Press.

Clark, D. L. (1999). Searching for authentic educational leadership in university graduate programs and with public school colleagues. In J. Murphy, \& P. B. Forsyth (Eds.), Educational administration: A decade of reform (pp. 228-236). Thousand Oaks, CA: Corwin Press Inc.

Costas, B., (2000). Fair Ball. New York: Broadway Books.

Culbertson, J. A. \& Hencley, S. P. (1962). Preparing administrators: New perspectives. Columbus, $\mathrm{OH}$ : The University Council for Educational Administration.

Duke, D. L. (1992). The rhetoric and the reality of reform in educational administration. Phi Delta Kappan, 73, 764-770.

Dryfoos, J. G. (1994). Full service schools: A revolution in health and social services for children, youth, and families. San Francisco: Jossey-Bass.

Duke, D. L. (1992). The rhetoric and the reality of reform in educational administration. Phi Delta Kappan, 73, 764-770.

Forsyth, P. B. (1999). Redesigning the preparation of school administrators: Toward consensus. In S. D. Thompson (Ed.), School leadership: A blueprint for change (pp. 23-33). Newbury Park, CA: Corwin Press Inc.

Fusarelli, L . D., \& Smith, L. (1999). Improving urban schools VIA leadership: Preparing administrators for the new millennium. Journal of School Leadership, 9(6). 534-551.

Gmelch, W.H. \& Miskin, V. D. (1995). Chairing an academic department. Thousand Oaks, CA: Sage Publications, Inc.

Griffiths, D.E., Stout, R. T., \& Forsyth, P. B. (Eds.). (1988). Leaders for America's schools. Berkeley, CA: McCutchan Publishing Corporation.

Guthrie, J. W., Sanders, T. (2001, January 7). Who will lead the public schools? The New York Times, $4 A, 46$.

Hart, A. W., \& Pounder, D. G. (1999). Reinventing preparation programs: A decade of activity. In J. Murphy, \& P. B. Forsyth (Eds.), Educational administration: A decade of reform (pp. 115-151). Thousand Oaks, CA: Corwin Press Inc.

Houston, P. D. (1998). The ABCs of administrative shortages. Education Week, 32 \& 44.

Jacobson, S. L., Emihovich, C, Helfrich, J., Petrie, H. G., \& Stevenson, R. B. (1998). Transforming schools and schools of education: A new vision for preparing educators. Thousand Oaks, CA: Corwin Press

Leithwood, K., \& Steinbach, R. (1995). Improving the problem-solving expertise of school administrators. In K. Leithwood \& R. Steinbach (Eds.), Expert problem solving: Evidence from school leaders(pp.281-309). New York: SUNY Press.

Lomotey, K. (1989). African-American principals: School leadership and success. New York: Greenwood Press.

Lord, M. (2000). Hello? Anybody there? School districts scramble to fill principals' chairs. U.S. News \& World Report, 129 (6), 43.

McCarthy, M. M. (1999). The evolution of educational leadership preparation programs. In J. Murphy \& K. S. Louis (Eds:), Handbook of research on educational administration ( $2^{\text {nd }}$ ed., 
pp. 119-139). San Francisco: Jossey Bass.

McCarthy, M. M. \& Kuh, G. D. (1997). Continuity and change: The educational leadership professoriate. Colmbia, MO: The University Council for Educational Administration.

McCarthy, M., Kuh, G., Newell, L., \& Iacona, C. (1988). Under scrutiny: The educational administrations professorate. Tempe, AZ: University Council for Educational Administration.

Miklos, E. \& Ratsoy, E. (1992). Educational leadership: Challenge and change. Edmonton, Alberta, Canada: Deparement of Educational Administration.

Milstein, M. (1993). Changing the way we prepare educational leaders: The Danforth experience. Newbury Park, CA: Corwin Press.

Milstein, M. N., Bobroff, B. M., \& Restine, L . N. (1991). Internship programs in educational administration. New York: Teachers College Press.

Morgan, G. (1997). Images of organization (2nd ed.). Thousand Oaks, CA: Sage Publications.

Murphy, J. (1992). The landscape of leadership preparation: Reframing the education of school administrators. Newbury Park, CA: Corwin Press.

Murphy, J. (Ed.) (1993). Preparing tomorrow's school leaders: Alternative designs. University Park, PA: University Council for Educational Administration.

Murphy, J. (1999a). The quest for a center: Notes on the state of the profession of educational leadership. [Monograph]. Columbia: MO: University Council for Educational Administration, 1-88.

Murphy, J. (1999b). Changes in preparation programs: Perceptions of department chairs. In J. Murphy, \& P. B. Forsyth (Eds.), Educational administration: A decade of reform (pp. 170191). Thousand Oaks, CA: Corwin Press Inc.

Nonaka, I., \& Takeuchi, H. (1995). The knowledge creating company. New York: Oxford University Press.

Olson, L. (2000). Policy focus converges on leadership: Several major efforts underway. Education Week. [On-line] Available: www.edweekorg/sreports/

Osterman, K. (1990). Reflective practice: A new agenda for education. Education and Urban Society, 22(2), 133-152.

Owens, R. G., \& Steinhoff, C. R. (1992). Beyond the administrative internship: A proposal for the 1990's. In F. C. Wendel (Ed.)., Reform in administrator preparation: Myths, realities and proposals. University Park, PA: The University Council for Educational Administration.

Parker, L., \& Shapiro, J. P. (1992). Where is the discussion of diversity in educational administration programs? Graduate students' voices addressing an omission in their preparation. Journal of School Leadership, 2 (1), 7-33.

Pitner, N. J. (1988). School administrator preparation: The state of the art. In Griffiths, D. E., Stout, R. T., \& Forsyth, P. B. (Eds.). Leaders for America's schools. (pp. 367-402). Berkeley, CA: McCutchan Publishing Corporation.

Robelen, E. (2000, March 8). President seeks bigger budget for research. Education Week, 30.

School Administrators of Iowa. (1998, May 19). Policy statement on the school administrator shortage. http://www/sai-iowa org/shortDE.html. January 20, 1999.

Scheurich, J. (1994). Policy archeology: A new policy studies methodology. Journal of Education Policy, 9(4), 297-316.

School Administrators of Iowa. (1997, October 27). Summary: Leadership in crisis. http://www/sai-iowa.org/short2.html. January 20, 1999.

Sergiovanni, T. (1991). The principalship: A reflective practice perspective.( $\left.2^{\text {nd }} \mathrm{ed}.\right)$. Boston: Allyn \& Bacon.

Sergiovanni, T. (1994). Organizations or communities? Changing the metaphor changes the theory. Educational Administration Quarterly, 30(2), 214-226. .

Short, P. M. (1997). Reflection in administration preparation. Peabody Journal of Education, 72 (2), 86-99

Starratt, R. J., \& Foster, W. (1994). Educational administrators as leaders: Research implications. In T. A. Mulkeen, N. H. Cambron-McCabe, \& B. J. Anderson (Eds.). Democratic leadership: The changing context of administrative practice. Norwood, NJ: Ablex. 
Thomson, S. D. (1999).Causing change: The national policy board for educational administration. In J. Murphy, \& P. B. Forsyth (Eds.), Educational administration: A decade of reform (pp. 93-114). Thousand Oaks, CA: Corwin Press Inc.

UCEA Review, XLII, 1 (Winter,2000). Columbia, MO: University Council for Educational Administration

UCEA Review, XLII, 2 (Spring, 2001). Columbia, MO: University Council for Educational Administration

Van Meter, E. J. (1999). The persistent saga: Changing instruction and curriculum to better prepare school leaders. In J. Murphy, \& P. B. Forsyth (Eds.), Educational administration: A decade of reform (pp. 170-191). Thousand Oaks, CA: Corwin Press Inc.

Walker, D. (1995). The preparation of constructivist leaders. In L. Lambert, D. Walker, D. P. Zimmerman, J. E. Cooper, M. D. Lambert, M. E. Gardner, \& P. J. Ford Slack (Eds.), The Constructivist Leader (pp. 171-189). New York: Teachers College Press.

Wendel, F. C. (Ed.). (1992). Reform in administrator preparation: Myths, realities and proposals. Tempe, AZ: The University Council for Educational Administration.

Young, M. D., \& Petersen, G. J. (2000, November 1). Nonprofit group aims to groom new breed of leaders [Letter to the editor]. Education Weekly, p. 47.

\footnotetext{
'Throughout this manuscript, we use the term "educational leadership to refer to school administration, school leadership, and educational administration.

${ }^{2}$ We are, of course, aware that there have been many attempts to capture the landscape of leadership preparation and to document both progress and shortcomings in the field. However, what we have not seen is an analysis that places preparation within its complex and overlapping environments and then seeks to understand and analyze the factors that support and detract from a programs ability to provide quality leadership preparation.

${ }^{3}$ On the other hand, Clark (1999) pointed out that "the damage suffered within programs that accept and graduate below-standard master's and doctoral students in educational administration extends beyond the university into the school systems, which are plagued by these mediocre performers for years" ( $p$. 229).

${ }^{4}$ This address was later published as a monograph by the University Council for Eductional Administration and similar ideas appear in his book The Landscape of Leadership Preparation (1999).

${ }^{5}$ Recommendations for significant changes in such areas as the clinical experiences/ internships (Forsyth, 1992; Griffiths, Stout, \& Forsyth, 1988; Murphy, 1993; Owens \& Steinhoff, 1992;

Pitner, 1988); administrative skills (Murphy, 1999a); differential instructional methods (McCarthy et al., 1988); and changing the entire structure of preparation programs (Forsyth, 1992; 1999;

McCarthy, 1999; Short, 1997) have become commonplace in the literature of our profession
} 